\title{
DNA Interference Oligonucleotide PNT2258
}

National Cancer Institute

\section{Source}

National Cancer Institute. DNA Interference Oligonucleotide PNT2258. NCI Thesaurus.

Code $C 92588$.

A liposomal formulation of the 24-mer oligonucleotide PNT100, with potential antineoplastic activity. PNT 2258 targets and complements to untranscribed DNA sequence upstream of BCL2 promoters, thereby interfering with DNA replication and transcription of the BCL2 gene. This may promote and restore the apoptotic pathway in BCL2-overexpressing tumor cells. BCL2, an anti-apoptotic protein, is overexpressed in a wide variety of tumors. 